BULLETIN OF PNRPU. GEOLOGY. OIL \& GAS ENGINEERING \& MINING

ВЕСТНИК ПНИПУ. ГЕОЛОГИЯ. НЕФТЕГАЗОВОЕ И ГОРНОЕ ДЕЛО

ISSN 2224-9923

Volume/ ToM 16 №1 2017

http://vestnik.pstu.ru/geo/

УДК 544.77.022; 622.276.72

Статья / Article

(C) PNRPU / ПНИПУ, 2017

\title{
STUDY OF MECHANISM OF OIL MAGNETIC ACTIVATION IN ORDER TO PROTECT PRODUCTION WELLS FROM WAX DEPOSITION
}

\section{A.A. Zlobin}

Perm National Research Polytechnic University (29 Komsomolskii av., Perm, 614990, Russian Federation)

\section{ИЗУЧЕНИЕ МЕХАНИЗМА МАГНИТНОЙ АКТИВАЦИИ НЕФТИ ДЛЯ ЗАЩИТЫ ДОБЫВАЮЩИХ СКВАЖИН ОТ АСФАЛЬТЕНОСМОЛОПАРАФИНОВЫХ ОТЛОЖЕНИЙ}

\author{
А.А. Злобин \\ Received / Получена: 03.08.2016. Accepted / Принята: 03.03.2017. Published / Опубликована: 31.03.2017
}

Пермский национальный исследовательский политехнический университет (614990, Россия, г. Пермь, Комсомольский пр., 29)

\section{Key words:}

magnetic and hydrodynamic activation, wax deposition, nuclear magnetic resonance method, supramolecular asphaltene structures, aggregation and peptization of asphaltenes, paramagnetism, spin dynamics of radical pairs.

\section{Ключевые слова}

магнитогидродинамическая активация, асфальтеносмолопарафиновые отложения, метод ядерного магнитного резонанса, надмолекулярные асфальтеновые структуры, агрегация и пептизация асфальтенов, парамагнетизм, спиновая динамика радикальных пар.

\begin{abstract}
The purpose of the paper is experimental study and description of mechanism of magnetic and hydrodynamic (MHD) activation of oil for protection from wax deposition and to increase efficiency of heavy oil production. A brief review of history of magnetic activation (MA) application is performed. Laboratory methods used to record efficiency of MA are described. As a result of experiments several points were established. Firstly, a positive effect of protection from wax deposition is implemented for all types of oil, regardless composition and viscosity, but it is necessary to select individual activation regimes. Secondly, it is shown that magnitude of the "magnetic memory" of oil increases nonlinearly with increase of magnetic field strength and can reach 20-40 hours. Thirdly, a common resonance mechanism for MA of oil is established. Fourthly, a magnitude of MHD activation effectiveness is determined by content of asphaltene and resin matter, that is dispersed oil phase. A brief theory of spin dynamics of paramagnetic radical pairs which takes place when oil is activated is described. The mechanism of MHD activation is as follows: a magnetic field with a small amount of excitation energy in capacity selects chemical and physical reactions by controlling spin state of electrons and stimulates recombination and birth of paramagnetic radical pairs. That ensures appearance of long-term high-energy activity (phase transitions) of asphaltene molecules with emission or input of energy, leading to structural rearrangement of nuclei of asphaltene structures and physical macroparameters of oil as a whole. Wherein, the positive protective effect against wax deposition after MA is caused by aggregation and enlargement of asphaltene complexes, a decrease in specific adsorption surface of paraffin crystals and creation of harmonic vibration modes in oil matter, which reduce a probability of nucleation and subsequent growth of paraffin crystals. Obtained results can be used in development of modern methods for controlling the properties of oil dispersed systems and development of downhole and ground surface MHD activators.
\end{abstract}

Целью работы является экспериментальное изучение и описание механизма магнитогидродинамической (МГД) активации нефти для защиты от асфальтеносмолопарафиновых отложений (АСПО) и повышения эффективности добычи высоковязкой нефти. Проведен краткий обзор истории использования магнитной активации (МА). Описаны лабораторные методы, используемые для регистрации эффективности МА. В результате экспериментов установлено, что, во-первых, положительный эффект защиты от АСПО реализуется для всех типов нефти, независимо от состава и вязкости, но необходим выбор индивидуальных режимов активации. Во-вторых, показано, что величина «магнитной памяти» нефти нелинейно увеличивается с ростом напряженности магнитного поля и может достигать 20-40 часов. В-третьих, установлен общий резонансный механизм МА нефти. В-четвертых, величина эффективности МГД-активации определяется содержанием асфальтеносмолистых веществ, т.е. дисперсной фазы нефти. Описана краткая теория спиновой динамики парамагнитных радикальных пар, которая имеет место при активации нефти. Механизм МГД-активации заключается в том, что магнитное поле с малым запасом энергии возбуждения производит селекцию химических и физических реакций посредством управления спиновым состоянием электронов и стимулирует рекомбинацию и рождение парамагнитных радикальных пар, что обеспечивает проявление долговременной высокоэнергетической активности (фазовых переходов) молекул асфальтенов с выделением или поглощением энергии, приводящей к структурной перестройке ядер асфальтеновых структур и физических макропараметров нефти в целом. При этом положительный защитный эффект от АСПО после МА обусловлен агрегацией и укрупнением асфальтеновых комплексов, уменьшением удельной поверхности адсорбции кристаллов парафина и созданием в объеме нефти гармонических мод колебаний, снижающих вероятность зарождения и последующего роста кристаллов парафина. Полученные результаты могут быть использованы при разработке современных методов управления свойствами нефтяных дисперсных систем и разработке скважинных и наземных МГД-активаторов.

\footnotetext{
Aleksandr A. Zlobin (Author ID in Scopus: 36712914500) - PhD in technical sciences, Associate Professor at the Department of Oil and Gas Technologies
} (mob. tel.: +0079194570 538, e-mail: ZlobinAA55@gmail.com).

Злобин Александр Аркадьевич

наук, доцент кафедры нефтегазовых технологий (моб. тел.: +00791945 70538 , e-mail: ZlobinAA55@gmail.com). 


\section{Introduction}

Today a lot of major oil fields in Russia are on the final stage of development. Decrease in reserves and production rates of low viscosity light oil cause a need to find new hydrocarbon sources. Therefore, development of heavy oil fields is paid by significant attention nowdays. Heavy oil could be used both in short and long terms as a resource base to refill and increment hydrocarbon reserves.

Having 6.3-13.4 billion tons Russia takes third place in reserves of heavy hydrocarbon after Canada and Venezuela.

Artificial lift of unconventional heavy hydrocarbons leads to geological and technological issues caused by significant content of high molecular heterocyclic polydisperse compounds such as asphaltens and resins. These compounds lead to variety of problems due to the fact that they form wax deposition and water-oil emulsions on downhole pumping equipment of production wells [1].

During change of thermodynamic conditions in tubing there are phase changes from paraffin hydrocarbons to solid crystal state and aggregartion of supramolecular asphaltene structures (SMAS). That leads to decrease of its solubility and precipitation from oil in a form of adhesion-active complexes that create strong surface deposition cake.

Complexes of sphaltens and resins modificate growth of paraffin structures due to developed polar nature of asphaltenes and their high adhesion to metal. Organic deposition cause significant loss in oil production, decrease in productivity index, production rate, mean time between repair (MTBR), mean time between cleaning (MTBC) and other technological parameters of production well operation.

Control of wax deposition on field equipment is the most relevant for development of Perm region oil fields because there are $45 \%$ of wells with wax deposition out from total number of problematic wells, which represents $75 \%$ of total operating production wells.

One of the most efficient methods to control wax deposition is the use of chemicals such as inhibitor of wax deposition [2]. However, in order to use them it is important to do accurate screening of an efficient chemical agent and method to deliver to well bottomhole. It has to be said, that strong aromatic dissolvers of wax are highly toxic agents that negatively affect ecology and human.

Above mentioned proves that nowdays implementation of new alternative methods into oil production to control wax deposition based on water-oil composition activation with no agents used by wave magnetic field.

The subject is experimental study and characterization of mechanism of magnetic hydrodynamic (MHD) oil activation to control organic deposition and increase efficiency of production of heavy oil. There are no questions on relevance of the issue because there is enough field data (around several thouthands) about MHDAactivation gathered at this time [3]. Nevertelles, there is no scientific physical theory that could explain existence of positive effect and develop technological criteria of efficient oil activation.

\section{Hystory of water and oil magnetic activation}

The first information about influence of magnets on properties of water comes from medicine, since the XIII century (Geneva physicist de Gerlos). The most systematized information was obtained from the 1930s. XX century by Giorgio Piccardi, who on the basis of more than 250 thousand observations established a statistically significant relationship between the activity of the sun and sedimentation rate of bismuth oxychloride solin in water.

The beginning of industrial implementation of magnetic activation (MA) is considered 1945, when engineer $\mathrm{T}$. Vermeer patented a method for control scum that sediments out of water for steam boilers feeding [3]. Its essence lies in a fact that before operation water was treated with a permanent magnetic field, which almost prevented formation of solid inorganic deposits of calcium $\mathrm{CaCO}_{3}$ scale on walls of steam boilers and heat exchangers. Economic effect was exlained by an increase in life time of equipment and saving of repair costs.

Intensive research and implementation of MA fluids in the world began in the 50's of last century. The second wave of interest in magnetic activation of liquids occurred in 1995-2000 when a new 
generation of magnetic materials based on rareearth metals of group of neodymium, samarium and praseodymium appeared. In Russian market, first industrial wells magnetic conditioners such as M238j55, M278j55 Magniflo broduced by American company Mag-Well (Texas) appeared in 1989 and in 1993 in Perm region.

Despite the fact that today there is no strong theory of physics and mechanism of interaction between magnetic field (direct and alternate) with moving diamagnetic fluid, the fields of possible implementation of MA technology with no agents are expanding permanently. There are hundreds of patent application for magnetic activators. One of confirmations of high efficiency of magnetic devices is increasing attention paid to their use by various domestic and foreign companies, as well as growth of their production, sales and implementation in oil production.

At the same time, as it follows from many laboratory and field data, in addition to preventing and reducing deposition of wax and inorganic salts and improving environmental performance of oil production, use of magnetic devices also makes it possible to obtain a number of other useful technical effects. For example, corrosion protection of pipes and equipment is very important economically, technically and ecologically, since corrosion is a cause of many accidents of pipeline transport in oil fields. Use of magnetic activation of liquids for anticorrosion protection of pipelines is increasingly used in oil production.

Wave contactless effects on solid and liquid systems are used in physics, chemistry, medicine, energy, metallurgy, construction, paper, food, textile, woodworking, chemical, petroleum industries during production, transportation and industrial processing of hydrocarbons in oil refineries [4-8].

At present, there are three main directions have been identified that use magnetic devices in production, oil collection and transport systems [9]:

1. MHD-activation of produced oil to prevent (reduce rate of growth) waxes and inorganic salts formation, increase productivity and increase MTBC and MTBR of production wells.

2. Placement of magnetic devices on pipelines with liquid (water, oil, water-oil mixture, technological solutions) to reduce corrosion rate, increase life time and reduce costs of operating of main pipelines.

3. MHD-activation of water injected into injection wells for a reservoir pressure maintenance system (RPMS) and increase in oil recovery ratio.

Current stage of implementation of MA for needs of oil industry workers in Russia is characterized by transition to a mass industrial release of various devices designed to activate liquid media. Let's name only such figures. In 2003 Tekhinsnab LLC manufactured 500 MHD units for oil well treatment [10], in 1997-2004 Inkom-neft engineering company produced more than 300 UMZh-73 devices and developed a wide range of UMP-type devices for demulsifying oil, water treatment and protection from wax deposition, which were implemented in Bashneft oil company PJSC, Belkamneft OJSC, LUKOIL oil company PJSC, NGDU Arlanneft, NGDU Ufaneft, Uraineftegaz TPP [11-13]. Industrial production of magnetic activators-dewaxing agents is also established in Moscow (Spetsobespechenie LLC), Barnaul (SPIKOM LLC), Kaluga (ELMAR-PM CJSC), Ozersk (ELIS LLS, Chelyabinsk region) and others.

Based on PermNIPIneft brach of LUKOILPERM LLC in Perm of in 1993-2006 as a result of detailed laboratory studies and pilot tests with direct participation of the author on basis of powerful ceramic $\mathrm{NdFeB}$ magnets, designs of new universal borehole MHD activators on axial magnetic fields of type MAC-1, MAC-2 were first developed, patented and manufactured and groundbased MAN-4.0 [14, 15], which are distinguished by high efficiency indicators when working with sewage and oil [16]. Currently, there are more than 300 magnetic wells of various design working in Perm region.

\section{Experimental studies of oil magnetic activation}

Magnetic activation of oil is not something new, but logically fits into intensively developing direction of research on effect of weak impulse (IMP) and constant magnetic fields (MF) on the physical properties of diamagnetic materials (bioobjects, polymers, semiconductors, ionic and covalent crystals). All these numerous academic 
studies [17-20] confirm a possibility of changing and modifying physical properties of diamagnetic materials by weak magnetic fields.

The main intrigue and impassable interest in such studies are related to the fact that the observed effects can not be explained in terms of classical equilibrium thermodynamics. If we calculate magnetic field energy, which is $\approx \mu_{\mathrm{B}} \mathrm{H}$ ( $\mu_{\mathrm{B}}$ is the Bohr magneton and $\mathrm{H}$ is magnetic field intensity), then really magnetic fields reachable in a laboratory (up to $1 \mathrm{~T}$ ) can not affect molecular and chemical processes due to an absolutely small energy MP, which is $10^{6}-10^{8}$ times less than the thermal $k_{B} T$ ( $k_{B}$ is the Boltzmann constant and $T$ is the absolute temperature) or the energy of the chemical bond. From the point of view of direct energy impact, there is, as it is said, a prohibition, and a change in the physical properties of substances after a magnetic field is impossible. But practice shows the opposite. Effects of structure conversion exist. Consequently, the effect of the magnetic field is not related to energy of a magnetic field, but is due to occurance of other physical mechanisms of nonenergy action.

\section{Laboratory methods for determination of efficiency of magnetic treatment of liquid phases}

In order to establish action laws of MFs on liquid phases it is first and foremost necessary to have accurate reliable methods for determining the efficiency of magnetic treatment of real oil.

Viscous and various optical methods are often used during oil study [4, 21]. But before real oil samples are diluted with normal saturated alkanes (pentane, hexane) to artificially stimulate aggregation of asphaltenes. From author's point of view, this approach violates natural structure of colloidal systems and is a source of additional uncontrolled errors, as the processes of aggregation and deposition depend on a large number of factors.

The method of laboratory analysis of efficiency of magnetic treatment of oil, used in our experiments, is as close as possible to real field conditions both in terms of state and process of formation of wax deposits on walls of tubing. Experiments were performed with use of gravimetric technique of "cold metal plate", based on measurement of relative weight of wax deposited on surface of metal plates (ST-3 steel, analogue of tubing) placed in an initial blank oil sample and in an oil sample after magnetic activation. Effect of control of wax deposition is calculated by the formula

$$
\mathrm{E}_{\mathrm{MHD}}=\left(M_{I n i}-M_{M A}\right) / M_{I n i},
$$

where $M_{I n i}, M_{M A}$ are mass of wax deposition on plates for initial and activated oil samples respectively. In order to avoid accidental errors, calculation is carried out at least for 4-6 plates in each oil sample.

To simulate downhole conditions at which paraffin hydrocarbons are dissolved in oil, experiments on magnetic activation should be conducted at temperature above paraffin phase transition. For that oil is heated up to $48{ }^{\circ} \mathrm{C}$ before processing.

But the main distinguishing feature of our experiments on analysis of mechanisms of MA is use of modern precision method of proton nuclear magnetic resonance (NMR) [22-23], which allows monitoring of conversion of properties of liquid and solid phases at nanoscale of structural elements of native oil.

Oil extracted from the reservoir is a colloidal dispersed system. A feature of that system is existence of supramolecular asphaltene structures that represent internal adsorption complexes built from molecules of asphaltenes and resins, whose dimensions are 10-1000 times larger than molecular ones.

To analize aggregation mechanisms, the author first developed a mathematical model and a method for calculating structural parameters of the SMAS in heavy oil. As a structural model, a colloidal model is considered where asphaltenes are in oil in form of solid particles in a colloidal suspension stabilized by resins adsorbed on particle surface [22]. For the first time, it was possible to assess effect of MF on oil directly in situ according to dynamics of current nuclear radius of SMAS in oil of various composition and viscosity.

The Fig. 1 shows the graph of change in radius of asphaltene core after magnetic activation of oil in simplest unregulated AMC-2.5 activator during 
4.5 hours. It is seen that developed methodological approach provides a fairly powerful statistical base of experimental data, in order to process which it is needed to use entire arsenal of statistical methods and application programs.

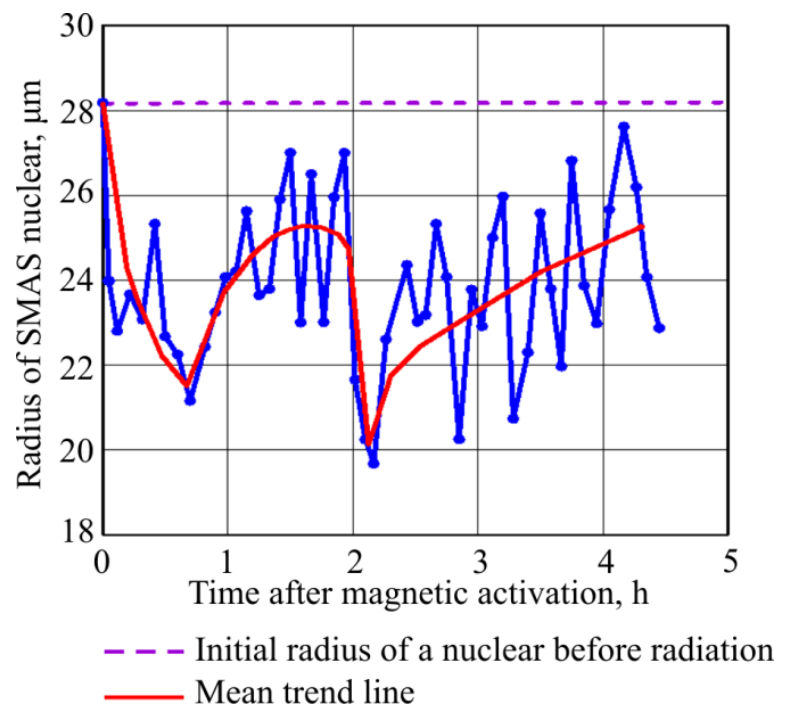

Fig. 1. Change in a radius of asphaltene core $\mathrm{R}_{\mathrm{cor}}$ after treatment of oil from Turkinskoe field in a well activator AMC-2.5 (Tiumen)

Using more than 70 types of specially designed original designs of activator models on rare-earth ceramic magnets, the author carried out hundreds of studies of features of influence of a magnetic field on physicochemical properties of oil produced. As a result, it has been experimentally proven that a positive effect in wax deposition control can be achieved on any oil sample, regardless of composition and viscosity, but it is necessary to select individual activation regimes. The last consist in establishment of optimal values of regulated parameters of the magnetic circuit of the MHD activator (a number and shape of active zones, location of zones in space, taking into account production rate) by conducting a series of laboratory design tests for MA with fluids from a formation of interst.

Secondly, it is established that magnitude of "magnetic memory" of oil increases nonlinearly with increasing magnetic field induction and can reach $20-40$ hours. The graph oh Fig. 2 shows a nonlinear (close to exponential) increase in magnetic memory of oil as a function of magnetic field induction B. New properties, for example, magnetoplasticity, can exist for months and years in solid bodies [18].
Magnetic memory is closely related to change in protective effect from wax deposition after MA, shown in Fig. 3 for four samples of oil from Perm region. It is established that for the memory of oil from induction of a magnetic field of average viscosity of oil there is a relatively short time dynamic transition period of 50-60 minutes of rapid growth in efficiency, followed by a stabilization interval. For high viscosity oil all internal processes are significantly stretched in time and maximum efficiency level can be realized in 7-10 hours, which is enough to protect entire tubing from a pump to a wellhead. Activation of oil samples in Fig. 3 was carried out in M6 model with a transverse magnetic field of $1.73 \mathrm{~T}$ and working gap of $10 \mathrm{~mm}$.

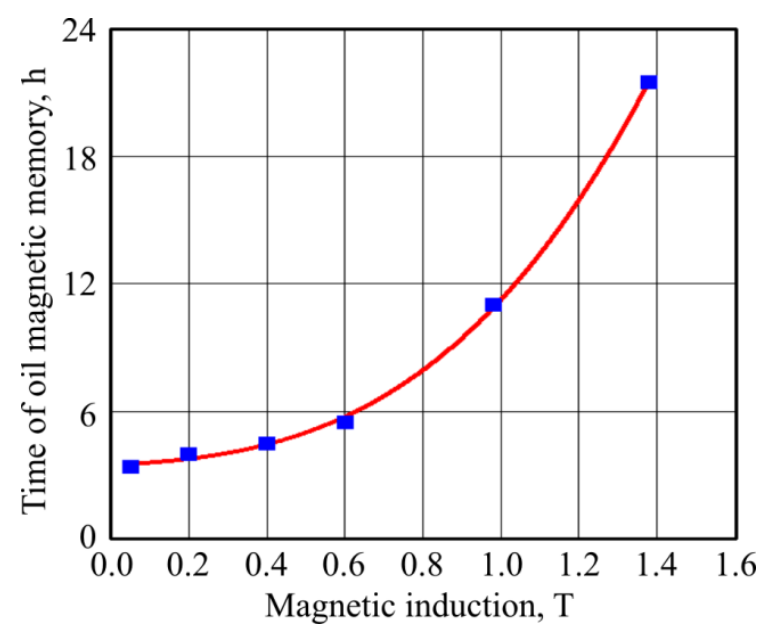

Fig. 2. Time dependence of magnetic memory from induction of magnetic field

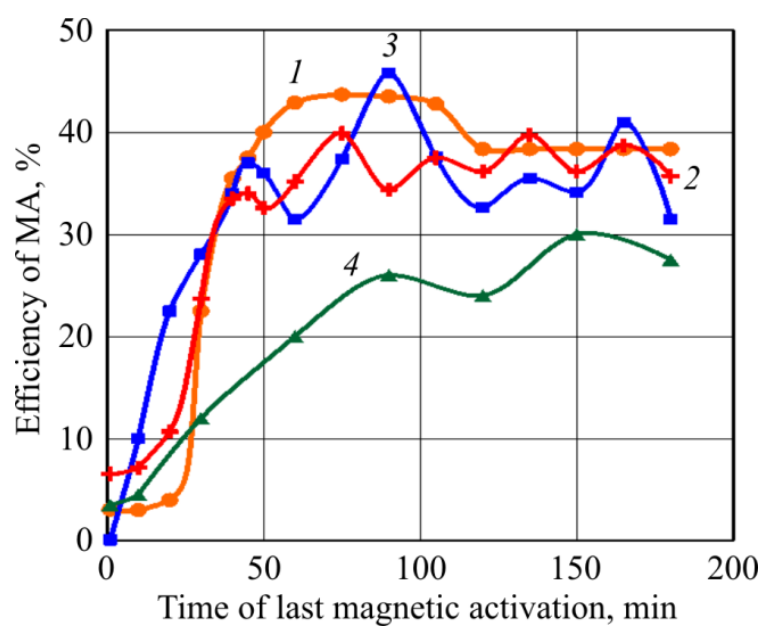

Fig. 3. Change in the protective effect of oil after magnetic activation in M6 model $\left(B_{\perp}=1.73 \mathrm{~T}\right)$ from Perm region fields: $1-$ Turkinskoe $(\mu=9.7 \mathrm{mPa} \cdot \mathrm{s})$; 2 - Gornovskoe $(\mu=8.2 \mathrm{mPa} \cdot \mathrm{s}) ; 3$ - Turkinskoe $(\mu=14.8 \mathrm{mPa} \cdot \mathrm{s}) ; 4$ - Padunskoe $(\mu=170 \mathrm{mPa} \cdot \mathrm{s})$ 
Thus, the total magnetic memory corresponds to a time interval of relaxation of a system from nonequilibrium activated state to equilibrium state. An interval is largely determined by the energy capabilities of the MHD activator structure and activation regime.

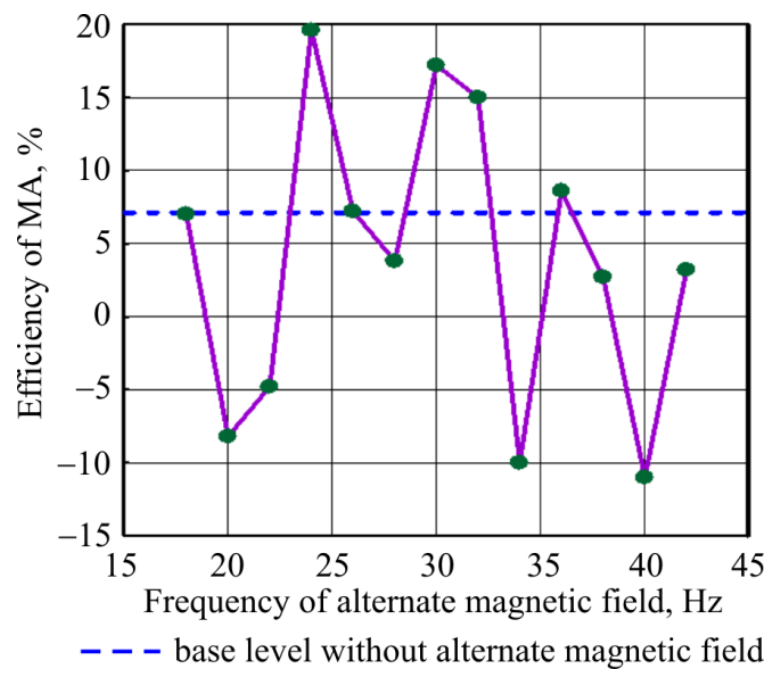

Fig. 4. Effect of frequency of alternate magnetic field on efficiency of oil activation from Turkinskoe field of M5 model $\left(B_{\perp}=1.2 \mathrm{~T} ; V=0.1 \mathrm{~m} / \mathrm{s}\right)$

Thirdly, a common resonance mechanism for oil MA has been established. Fig. 5 shows results of experiments on protection from wax deposition (cold metal plate method) on two models of activators. Besides, apart from constant MF presented in a model M5 there is an additional influence of weak alternate axial field on oil. The influence is formed in a solenoid by a sound generator GZ 56/1 in a frequency range of $18-50 \mathrm{~Hz}$. It is seen that there is a resonant enhancement of 2.86 times of protective effect with respect to the base effect in $7 \%$ at a frequency of 24, 30 and $32 \mathrm{~Hz}$. Fig. 5 reflects change in an amplitude of field modulation varied from 12 to $100 \mathrm{E}$ during activation of the LM model (laboratory electromagnet of EPRspectrometer RE1306). As a result, an asymmetric resonance dependence with a variation of efficiency of 2.29 times was obtained.

Resonance effects are also observed during change in design parameters of activators, for example, distance between sections, an angle between sections as it os shown in Fig. 6 for model M5-2 (two identical sections, transverse field $B_{\perp}=1.2 \mathrm{~T}$, gap $\left.-10 \mathrm{~mm}\right)$.

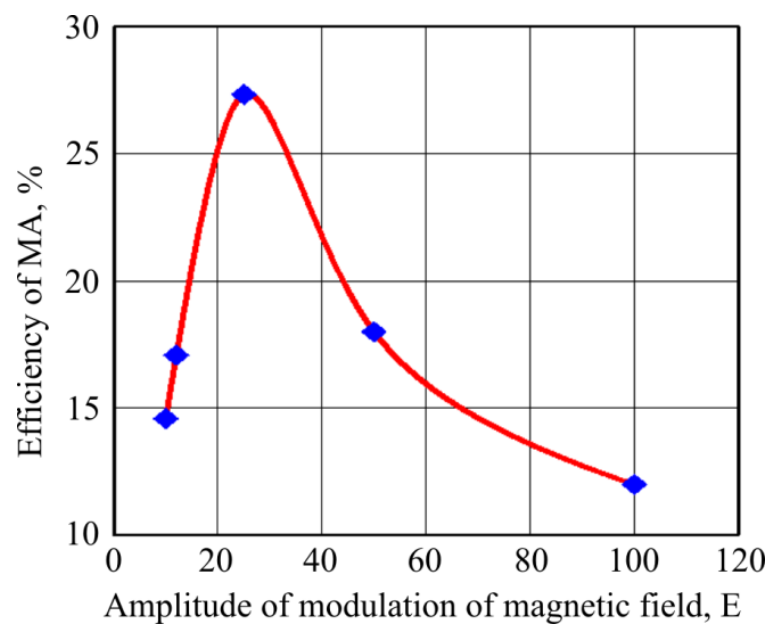

Fig. 5. Dependence of activation effect of oil from Kurbatovskoe field on amplitude of magnetic field modulation in a LM model

$$
\left(B_{\perp}=1.1 \mathrm{~T} ; V=0.3 \mathrm{~m} / \mathrm{s}\right)
$$

Figure 6, a confirms presence of a resonant distance between the active zones, equal to $35 \mathrm{~mm}$, and Fig. 6, $b$-resonant angle of shear. It is seen that influence of characteristic distance is less critical for efficiency of MA than change in angle between planes of polarization of two active zones. Only under condition of total inversion $\left(\Delta \varphi=180^{\circ}\right)$ of direction of magnetic flux resonance conditions occur in this model M5. In general, with an increase in induction of $\mathrm{MF}$, for example, in the M6 model up to $1.73 \mathrm{~T}$, a resonance area in neighborhood of 180 degrees broadens in 2.0-2.5 times, which increases probability of obtaining a higher and stable positive result.

Fourth, it has been experimentally established that magnitude of efficiency of MHD activation is determined by content of asphaltene and resin matter, i.e. dispersed phase of oil. Fig. 7 shows a graph of change in efficiency of MA of viscous oil and emulsions of five heavy oil fields that suffer wax deposition (Pervomaiskoe, Zmeevskoe, Berezovskoe, Padunskoe, Bugrovskoe) in south-western part of Perm region. Tuned well activators MAS-2-2.0 that have induction of axial field of $0.44 \mathrm{~T}$ and a channel in $50 \mathrm{~mm}$ in diameter were used to treat oil samples. It was established that at the interval of $44-630 \mathrm{mPa} \cdot \mathrm{s}$ (see Fig. 7) a linear increase in protective MHD effect is observed. An increase is associated with an increase in the content of asphaltenes an resins in oil from 20 to 45 wt. \%. Stability of such positive effect in the region of extremely viscous emulsions (above $1000 \mathrm{mPa} \cdot \mathrm{s}$ ) is lost as soon as mentioned upper boundary is passed. 


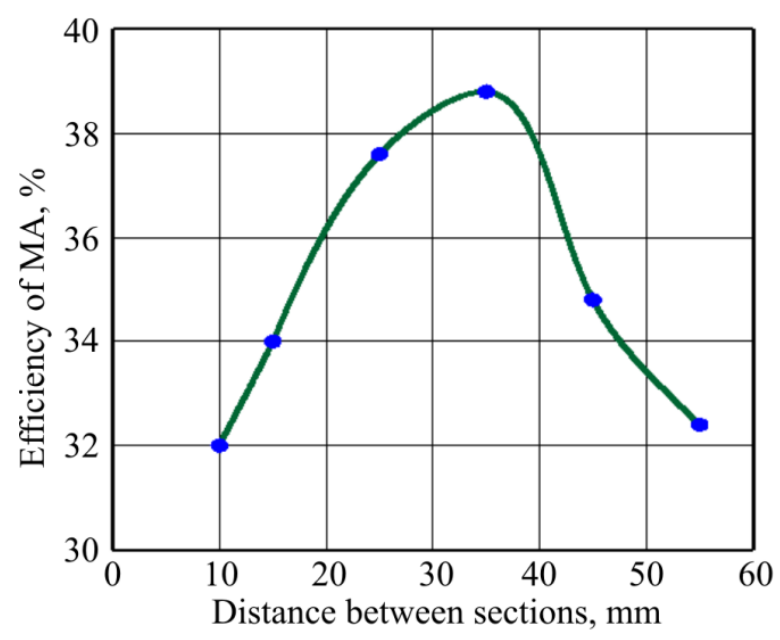

a

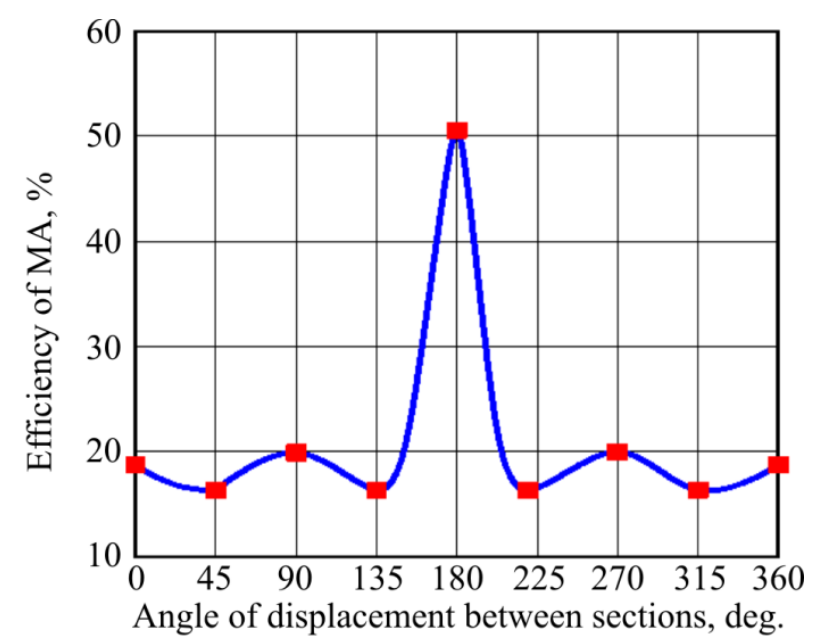

$b$

Fig. 6. Change in efficiency of MA in protection of Gornovskoe field oil from wax deposition with variation of distance between two sections $(a)$ and shear angle $(b)$ between sections around central axis in M5-2 model $\left(B_{\perp}=1.2 \mathrm{~T}\right)$

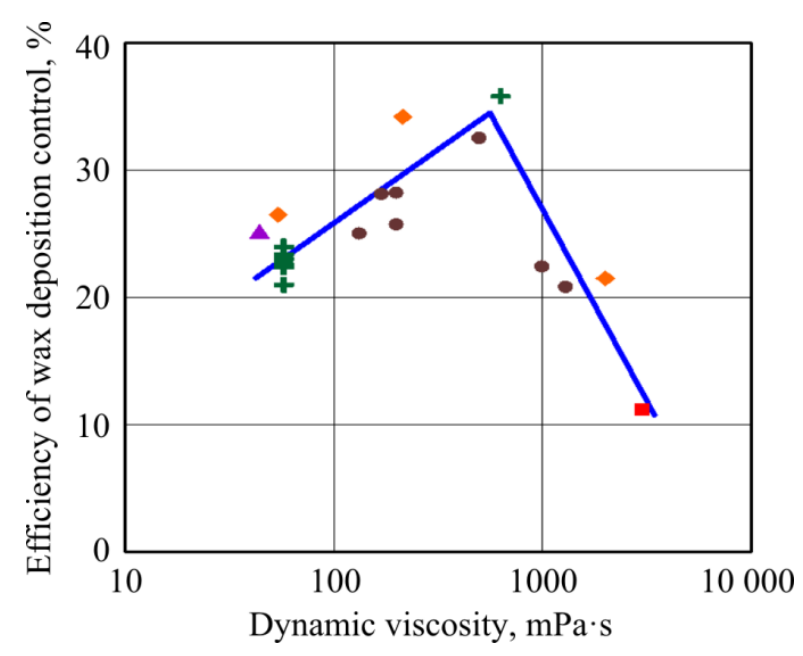

Fields:

$\Delta$ Pervomaiskoe + Berezovskoe $\diamond$ Zmeevskoe

- Padunskoe Bugrovskoe

Fig. 7. Dependence of protection effect on dynamic viscosity of heavy oil and emulsions while using MHD-activators of MAC-2 type

Above described results of wax deposition control effect during MHD activation reflect an overall technological effect but does not explain reasons and mechanisms of a magnetic effect. For this purpose, regularities of conversion of a structure of supramolecular asphaltene structures in oil under various regimes of magnetic activation have been studied. This is caused by the fact that the change in thermodynamic state of oil after MA occurs according to different and often opposite scenarios. In other words, various structural nanocomplexes and aggregates can be formed in the same oil that by a magnetic field. Those nanocomplexes and aggregates control physical properties of entire object, for example, process of wax precipitation during phase transition of paraffins.

As an example, two oil samples from Gornovskoe field, activated in a LM model under various modes at which magnetic zones were crossed, are presented on the Fig. 8. Dynamics of a radius of asphaltene core after magnetic activation was tracked in real time during experiments. Initial equilibrium state of an oil colloid system corresponds to core radius of SMAS of $25.3 \pm 0.5 \mathrm{~nm}$. During MA in static mode (Fig. 8, $a$ ) oil sample was moved in a container as a single volume without mixing the layers. After MA in static mode, SMAS asphaltene core is destructed nonpermanently in 1.53 times (from 24.8 to $16.2 \mathrm{~nm}$ ), which lasts 11 hours.

In the second case (see Fig. 8, $b$ ) of dynamic activation regime, oil was moved through a tube in a magnetic field at constant speed. After MA there was almost linear process of aggregation (consolidation) of nucleus SMAS from 25.7 to $31.2 \mathrm{~nm}$ (in 1.23 times) observed during first 1.8 hours. Then there is slower and complex superposition of peptization and aggregation of asphaltenes of nucleus in next 7.3 hours. It should be noted both described experiments have the same nature of long relaxation. Fig. 8, a and b shows clear vibrational processes different in amplitude and frequency, induced by a magnetic field. 

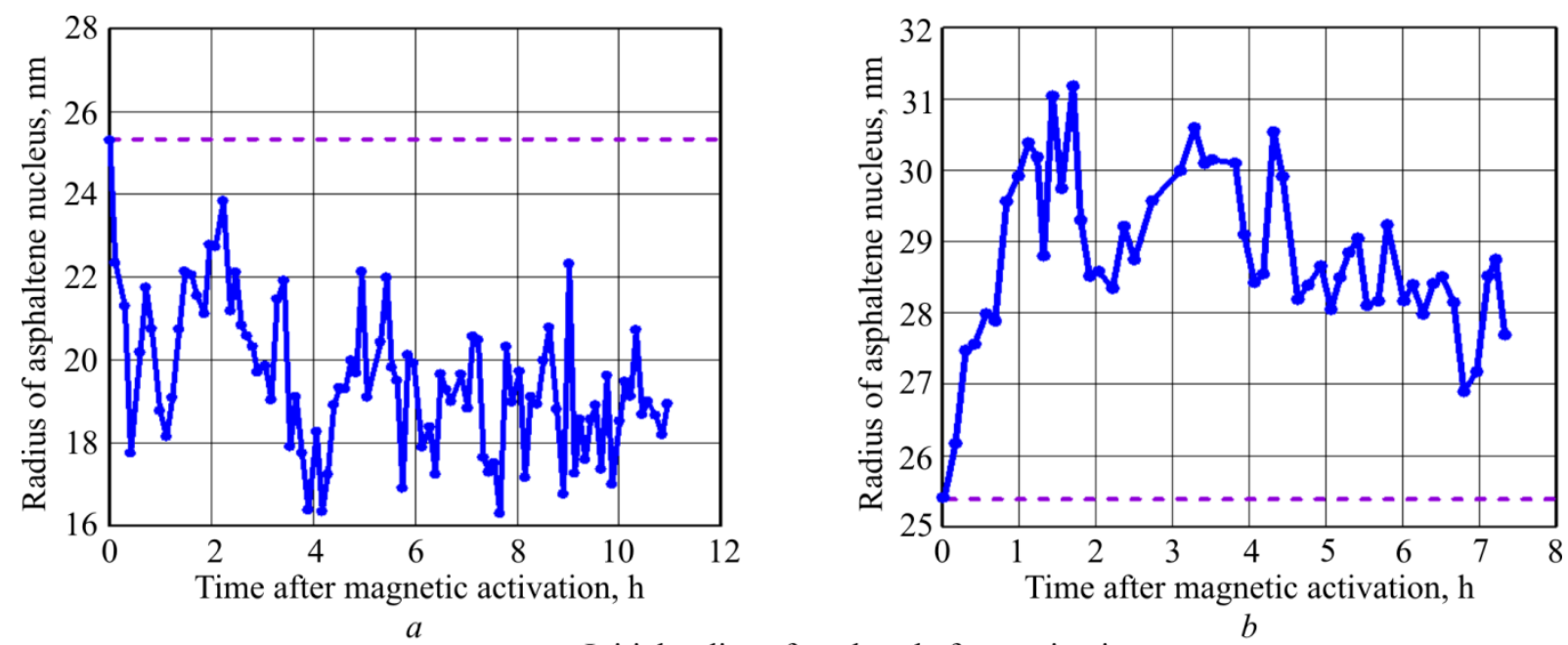

- - - Initial radius of nucleus before activation

Fig. 8. Dynamics of change of average radius of nucleus SMAS of Gornovskoe field oil after MA in static $(a)$ and dynamic $(b)$ modes of magnetic field in a model $\operatorname{LM}\left(B_{\perp}=1.35 \mathrm{~T} ; V=0.535 \mathrm{~m} / \mathrm{s}\right)$

The character of non-stationary processes after the MHD activation of oil samples was studied by time series analysis. The hypothesis of presence of regularity was tested by a discriminative method of time series by an analysis of Autocorrelations and Partial Autocorrelation Functions in the Statgraphics C-XV.1 package. Results obtained (Fig. 9) show

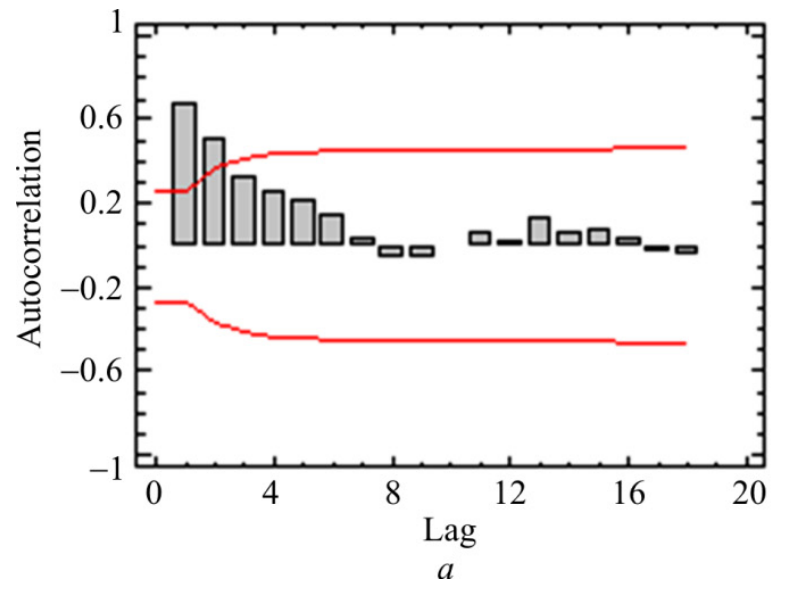

that studied time series on Fig. $8, b$ is not a random variable. Its regularity is expressed in a significant excess of $95 \%$ confidence limits (highlighted by a red line) of autocorrelation function for lags 1 and 2, and for frequency autocorrelation function for lag 1 . It can also be said that graphs demonstrate not just regularity but presence of a cyclic component.

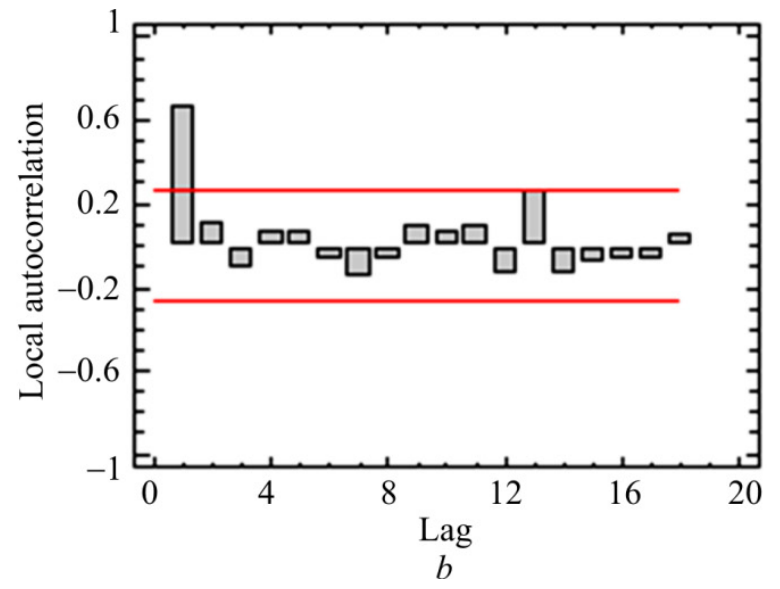

Fig. 9. Autocorrelation $(a)$ and local autocorrelation $(b)$ function of time series for dynamic regime of MHD-activation on Fig. $8, b$

\begin{tabular}{|c|c|c|}
\hline $\begin{array}{l}\text { Test } 1 \\
\text { Run above and below the median } \\
\text { Median }=9,14887 \\
\text { Number of runs above and below the median } \\
=\mathbf{1 3} \\
\text { Expected number of runs (for a random sequence) } \\
=\mathbf{2 8 , 0} \\
\text { Full test and statistics of a sample } \\
z=3,98417 \\
P \text {-criterion }=0,0000677484\end{array}$ & $\begin{array}{l}\text { Test } 2 \\
\text { Run above and below (confidence limits) } \\
\text { Number of runs above and below (confidence } \\
\text { limits) }=\mathbf{2 5} \\
\text { Expected number of runs (for a random sequence) } \\
=\mathbf{3 5 , 6 6 6 7} \\
\text { Full test and statistics of a sample } \\
z=3,33777 \\
P \text {-criterion }=0,000844642\end{array}$ & $\begin{array}{l}\text { Test } 3 \\
\text { Test }- \text { breakdown } \\
\text { Test on the base of the first } \mathbf{1 8} \text { autocorrelations } \\
\text { Full test and statistics of a sample (for a random } \\
\text { sequence) }=\mathbf{5 4 , 6 8 0 4} \\
P \text {-criterion }=0,0000143686\end{array}$ \\
\hline
\end{tabular}

Figure 10. Results of statistical tests on irregularity of time series presented on Fig. $8, b$ 
In addition, based on three independent statistical Tests for Randomness (Fig. 10), each of which is sensitive to various aspects of deviation from a random sequence. It is possible to assert with $95 \%$ confidence that the time series which describe the given relaxation process has a highlighted regular component (harmonic).

Thus, mixing of liquid layers during flow through MHD activator averages random stochastic oscillations to zero and enhances regular modes of own internal oscillations associated with self-organization and restructuring of the SMAS structure.

Additional comparison of structural parameters of SMAS with data derived from the method of deposition on a cold metal plate showed that a positive effect of wax deposition control in $15 \%$ was obtained only in dynamic activation regime (see Fig. 8, $b$ ), when the magnetic field initiates the process of aggregation of asphaltenes and radius of a SMAS nucleus increases.

Such a hypothesis has been verified on oil samples from other deposits with different composition and viscosity. The Fig. 11 shows
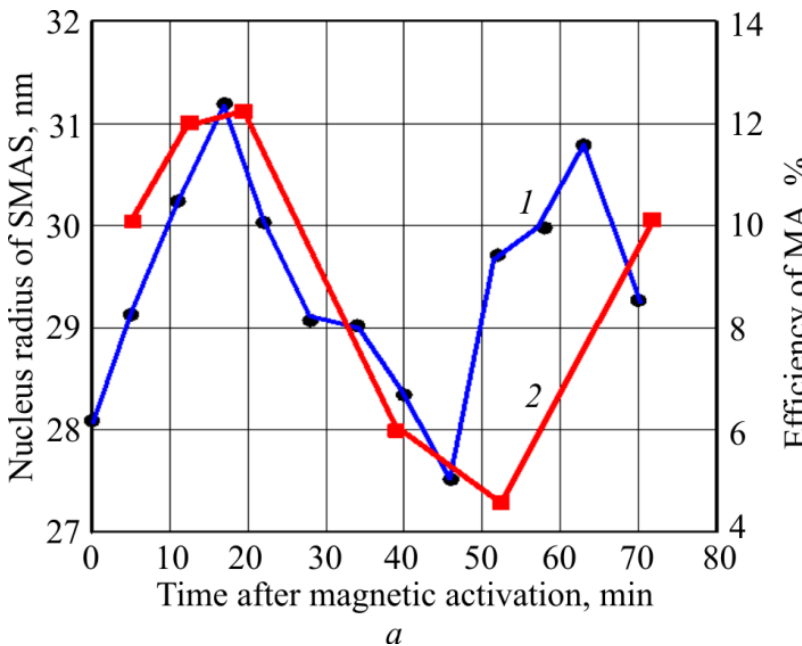

Fig. 11. Correlation between average radius of the core SMAS (1) and value of protection effect (2) for two samples of oil from Turkinskoe field in the experiments with well activator of MAC-1-2,5-2 type $\left(\mathrm{B}_{\mathrm{II}}=0.44 \mathrm{~T}\right.$; work channel diameter $\left.-63 \mathrm{~mm}\right)$

\section{Mechanism of magnetic hydrodynamic oil activation}

Taking into account results of research of many authors first of all it needs to answer what driving forces lead to formation and destruction of supramolecular structures in oil after MA. It is

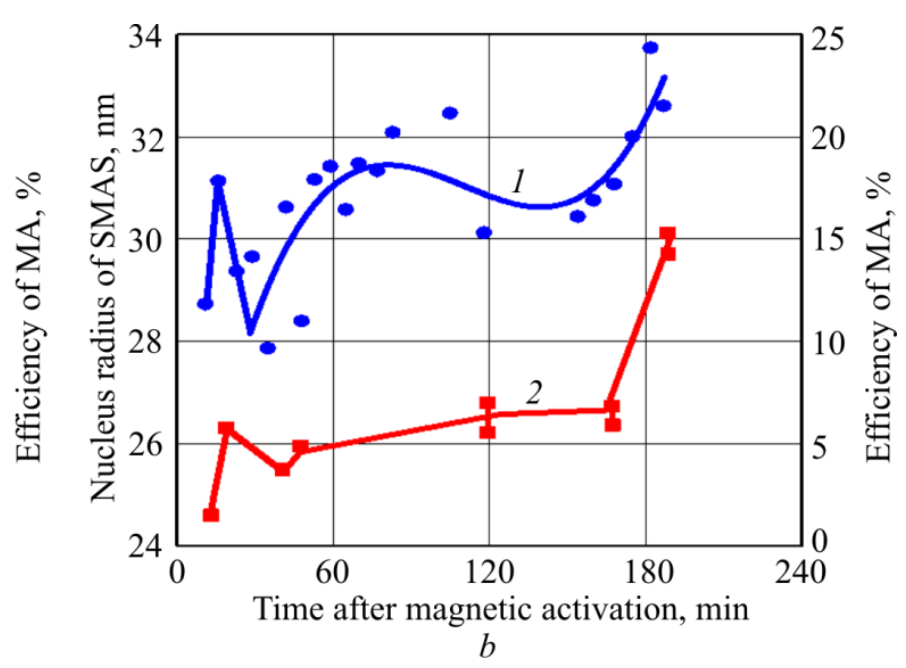

correlation between SMAS radius and magnitude of protective effect after MA for two samples of oil from Turkinskoe field. Treatment was carried out in a well activator of MAC-1-2,5-2 type at two different flow rates -0.112 and $0.057 \mathrm{~m} / \mathrm{s}$ and at different times. The Fig. 11 shows that growth dynamics of relative weight of was deposited on plates (protection effect - the red line) in macrovolume in two experiments a and b, carried out with an interval of 8 days, shows the same change in internal nanoparameter of SMAS structure in time (blue line) with a correlation coefficient 0.773 . At the same time, high values of the protection effect that control wax deposition are achieved at maximum radius of asphaltene core such as $12 \%$ at $31.2 \mathrm{~nm}$ and $15 \%$ at $33.3 \mathrm{~nm}$. Observed sharp breaks for the core radius in the first $60 \mathrm{~min}$ after activation reflect a similar process of reduction and growth of paramagnetic centers in oil. That for example could happen when oil is heated [24, 25]. Sharp brakes are associated with recombination and production of free radical pairs in paramagnetic asphaltenes.

necessary to understand nature of native oil. It is not a homogeneous flow fluid, but a complex multicomponent disperse system consisting of a solvent (non-polar dispersion medium) and a certain amount of dispersed particles. Composition of the solvent is mainly represented by high molecular weight chain saturated with paraffin 
hydrocarbons with some amount of naphthenic (cyclic) and aromatic hydrocarbons. Dispersed oil phase is represented by non-hydrocarbon highmolecular, close to polymers, heteroatomic components of thermal cracking of hydrocarbons such as oil resins and asphaltenes, which have high chemical activity. Resins are intermediate compounds between hydrocarbons and asphaltenes. It is believed that asphaltenes are products of resin condensation. According to aggregate state resin are viscous polydisperse nonstructured fluids, and asphaltenes are hard type, partially crystalline (1-5\%) substances, insoluble in paraffin hydrocarbons. Oil resins are highly soluble in hydrocarbons and represent solvate shell around asphaltene aggregates. Asphaltenes do not dissolve in paraffinic hydrocarbons, but dissolve in aromatic solvents [21]. If there are no resins asphaltene molecules form large aggregates and precipitate. Therefore, kinetic stability of supramolecular asphaltene structures is determined by size of an asphaltene core and thickness of a solvate screen shell made from diamagnetic resin molecules.

Distinctive features of asphaltenes are paramagnetic properties, which are determined by the content of paramagnetic centers in an amount of $10^{18}-10^{19} \mathrm{spin} / \mathrm{g}$. It was established that concentration of paramagnetic centers in oil with small amount of paraffins is proportional to content of asphaltene and resin containing matter. Asphaltenes, according to F.G. Unger, are "100\% concentrate of paramagnets" [24]. Appearance of paramagnetism of oil is associated with homolytic dissociation, where chemical bonds in neutral diamagnetic molecules are broken. That leads to separation of a pair of electrons, and as a result, two molecules with an unpaired electron (radical pairs) appear. Observed number of paramagnetic centers in asphaltene nuclei is determined by the dynamic equilibrium between processes of generation (creation) and recombination (annihilation) of radical pairs. During recombination of radical pairs an amount of energy released is equal to an amount needed for dissociation into radicals of 300-500 kJ/mol [26].

It is precisely the structural conversion in solids established during experiments such as photoconductivity of crystals relative to hardness of polymers [6] and magnetoplasticity of crystals [18], and in liquid natural oil is associated with evolution of electron-spin states of radical pairs whose spin is controlled by a magnetic field.

Brief aspects of a theory of radical pairs is considered following $[19,20]$. Spin (spin quantum number) $\mathrm{s}$ is a quantum characteristic of elementary particles (electron, positron, proton, neutron etc.), that reflects existence of angular momentum. Presence of a spin causes appearance of a magnetic moment in a particle, for example an electron, which represents a microscopic magnet. Projections of spin and magnetic moment of an electron on an random $Z$ axis in space are quantized, i.e. they can take only discrete values of $s_{z}$, number of which equals to $(2 s+1)$, and for an electron with spin $s=1 / 2$ it is equal to two energy states (a double). Quantum states are energy-degenerated (energy equals to each other) when there is no MF. When an external magnetic field is applied, degeneracy is removed by the interaction of magnetic moment of an electron with a magnetic field (Zeeman effect) and two energy levels appear. That corresponds to two directions of circular precession of spin $s$ along $(a)$ and across $(b)$ direction of a magnetic field $H-$ on a vector model (Fig. 12). Motion in a magnetic field is characterized by Larmor frequency $\omega=e \mathrm{H} / m c$ ( $e$ is electron charge, $m$ is mass and $c$ is speed of light). Objects whose energy level does not split in a magnetic field have a spin equal to zero $(s=0)$, they are said to be in single spin state of $S$.

If spin equalt to one $(s=1)$ that corresponds to triple state because there are three $(2 \cdot 1+1)$ energy levels in a magnetic field $T_{0}, T_{+}$and $T_{-}$ (Fig. 13).

Let us investigate the mechanism of formation and recombination of radical pairs. For a diatomic diamagnetic molecule, the process of dissociation can be considered in Fig. 14, where the lower energy term $S$ corresponds to a pair of electrons on molecular orbitals having antiparallel spins $\uparrow \downarrow$, i.e. the total spin of a system is zero (single state). Dissociative term $T$ is potential energy of a system in which two electrons have parallel spin orientation $\uparrow \uparrow$ and total spin of a system is 1 (triple state). 

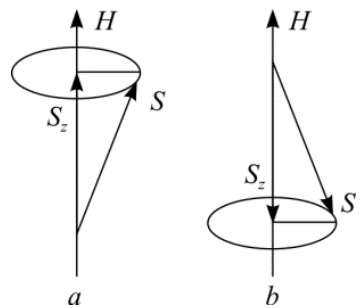

Fig. 12. A vector model of Zeeman of energy splitting into two levels (double) for an electron in a magnetic field: $a$ - lower, $b$ - upper levels

The first scenario of dissociation of a neutral molecule is possible from the main singlet state under thermal action. Resulting pair of radicals has the same single state as a disintegrated molecule, i.e. spins are antiparallel. The second scenario of dissociation is possible from electronically excited triplet state as a result of action of photons of light or other radiations. In this case, parallel orientation of spins is maintained in a resulting pair of radicals, and we obtain a radical pair in triple state. Thus, during homolytic dissociation, paramagnetic radical pairs arise either in the single or in triple state.

If a reverse process of recombination of radical pairs with formation of a chemical bond is considered, that random collisions of radicals having antiparallel spins (in the single state) have a maximal probability. Such collisions occur quickly and efficiently. But if colliding radicals have parallel spins (in triple state), then in general such a reaction is less possible. Recombination from triple into singlet state is completely forbidden, since initial and final spin states do not coincide.

Let us consider a scenario of recombination of unbound, diffusion radical pairs, which originated at a distance from each other. In this case, spin state of radical pairs will be random. Some of them will be in single state, and other part in triple state.

Consider that recombination of radical pairs occur when an external magnetic field $H$ is applied. Fig. 15 shows the radical pair $s_{1}$ and $s_{2}$, the projections of magnetic moment $s_{1}{ }^{z}$ and $s_{2}{ }^{z}$ of which turned out to be directed to different directions when encountered, and precession of these radicals occurs in antiphase. In this case, total spin of a system of radical pairs and total projection of their magnetic moments is zero.

In this case, total spin of a system of radical pairs and total projection of their magnetic moments is zero. This means that a radical pair is in single $S$ state, in which a recombination reaction is possible. Fig. 15 shows three triple states, when total spin of a pair is one. For state $T_{0}$, projections of magnetic moments of radicals are directed in different directions and total projection is zero. However, spin precession occurs in-phase, thus total spin of a system is $s=1$. For upper $T_{+}$and lower $T_{-}$spin states, projections of magnetic moments of both radicals are directed either against direction of external magnetic field or over a field at which total spin of a system is also 1 .

Thus, one single and three triple states of radical pairs appear in a magnetic field. In single state, recombination occurs in the same way as in absence of a field. But in triple states, that were previously forbidden in the spin, a constant magnetic field opens an additional recombination channel. While considering triple radical pair it could be presented in one of three spin stated after Zeeman splitting. As it can be seen from Fig. 15, for transition from triple $T_{+}$and $T_{-}$states to single state $S$ (Fig. 15), it is necessary that one of radicals change direction of projection of magnetic moment of spin to opposite, i.e. turned over. That requires a lot of energy, and so reaction is unlikely to work. At the same time, for transition from $T_{0}$ to $S$ state, it is necessary that in-phase precessing spins (see Fig. 15, $T_{0}$ ) become precessing in antiphase (see Fig. 15, $S$ ), which does not relate to a system energy change. 
To perform triple-single $T_{0} S$ transition, phase difference between precessing spins should reach a value of $\pi\left(180^{\circ}\right)$ [20]. Therefore, it is obvious that any physical effects that can change phase of precession of
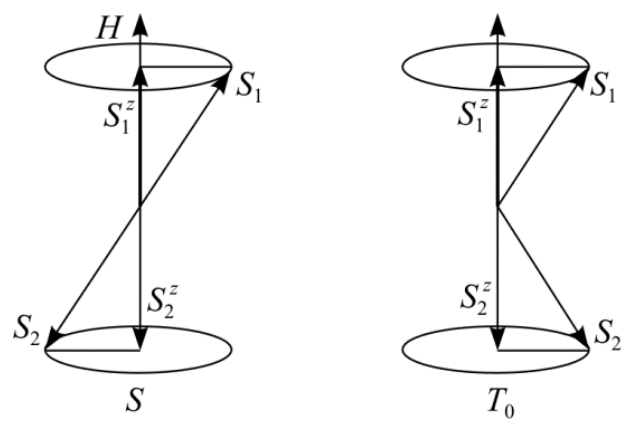

spins of radical pairs will cause $T_{0}-S$ transitions in a radical pair. Two basic mechanisms of triple-single transitions in a radical pair are known such as $\Delta g$ mechanism and EFI-mechanism (extra fine interaction).
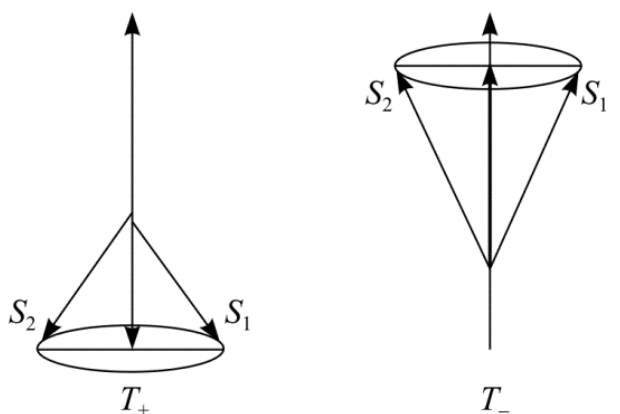

Fig. 15. Single $S$ and three triple states $T_{0}, T_{+}$, and $T_{-}$of a diffusion radical pair $\mathrm{s}_{1}$ and $\mathrm{s}_{2}$ in an external magnetic field

The essence of $\Delta g$-mechanism is as follows. The precession frequency of each electronic spin of a radical pair corresponds to resonance frequency of corresponding electron paramagnetic resonance of the transition:

$$
\omega_{1}=g_{1} \beta H / \hbar, \omega_{2}=g_{2} \beta H / \hbar,
$$

where $\omega_{1}$ and $\omega_{2}$ are precession frequencies of spins; $\beta$ is Bohr magneton; $g_{1,2}-$ g-factors of radicals of apair, $\hbar-$ Planck's constant. If frequencies of spins of a radical pair are different, then as a result of Larmor precession periodically in the radial pair there will be recombinations [20] at frequency equal to frequency difference of Larmor precession:

$$
\omega_{T_{o} S}=\left(g_{1}-g_{2}\right) \beta H / \hbar .
$$

The greater difference in $\mathrm{g}$ factors of radicals in a radical pair and the greater the intensity of a MP, the higher frequency or rate of evolution of radical pairs. A mechanism of extrafine Fermi interaction (EFI-mechanism) plays an important role if radicals in a radical pair have magnetic nuclei in their structure. In this case, a magnetic core creates an additional magnetic field on an unpaired electron and precession frequency changes due to superposition of this additional field. Difference in precession frequencies, which leads to spin conversion, is

$$
\omega_{1}-\omega_{2}=\left(g_{1}-g_{2}\right) \beta H / \hbar \pm \alpha / 2 \hbar,
$$

where $\alpha$ is extra fine interaction energy. In such a radical pair, rate of spin conversion is determined simultaneously by $\Delta g$ and EFI-mechanisms.
Neverthelles, contribution of EFI-mechanisms in strong magnets is negligeble.

It should be specially emphasized that $\Delta \mathrm{g}$ and STB mechanisms of triple-single transition always have a resonance character, which is presented in experiments described above with native oil containing paramagnetic radicals in the nuclei of supramolecular asphaltene structures. In addition, we note that spin evolution of radical pairs in the SMAS nuclei proceeds more intensively and with high probability due to fulfillment of conditions of "cellular" mechanism [20] that increases the lifetime of a pair, since radicals react in a compact local region of a nucleus separated from Solvent with a solvated resin shell.

Above described theory of radical pairs pertains to action of a stationary magnetic field. MHD activators developed by the author in practice are used. Their design contains principles of periodic artificial inversion of direction of an axial magnetic field by generating alternating pulses of magnetic fields in a moving oil stream. This leads to a reversal of spins of radical pairs from upper precession cone to lower one (see Fig. 15) and provides triple-single recombination of radical pairs through an additional channel of Zeeman levels $T_{ \pm} S$ closed at a constant magnetic field.

An impulse and resonance mechanism for controlling spin dynamics of radical pairs of asphaltenes additionally increases efficiency of magnetic activation of native oil. That is confirmed in experiments by dependence of the protective 
effect on induction of a magnetic field, whose characteristic only of transitions between Zeeman levels $T_{ \pm}$, while $T_{0-S}$ transition does not depend on a field value [19].

Thus, a magnetic field with small excitation of energy performs chemical and physical reactions by controlling spin state of electrons and stimulates recombination and birth of paramagnetic radical pairs. That ensures appearance of long-term high-energy activity (phase transitions) of asphaltene molecules with release or absorption of a sufficiently high energy. That leads to structural reconstruction of SMAS nucleus and physical macro parameters of entire oil. Herewith, positive protective effect of wax deposition after activation happens due to aggregation and inlargment of SMAS complexes, decrease in specific adsorption surface of paraffin crystals, and the creation of harmonic vibration modes in oil volume. That reduces a probability of nucleation and subsequent growth of paraffin crystals.

\section{Conclusion}

1. As a result of experiments, firstly, it was proved that positive effect on protection from wax deposition is implemented for all oil samples, regardless of composition and viscosity, but it is necessary to select individual modes of MHD-activation. Secondly, it is determined that magnitude of "magnetic memory" of oil increases nonlinearly with increase in a magnetic field strength and can reach 20-40 hours. Thirdly, a common resonant mechanism of oil activation is established. Fourthly, magnitude of effectiveness of MHD activation is determined by the content of asphaltene and resin substances in native oil.

2. A mechanism of MHD activation is caused by selective effect of a magnetic field on electronspin state and evolution of paramagnetic radical pairs of asphaltenes, which leads to structural rearrangement (aggregation and peptization) of supramolecular asphaltene structures and changes in physical macroparameters entire oil (viscosity, temperatures of saturation of oil with paraffin etc.).

\section{References}

1. Ganeeva Iu.M., Iusupova T.N., Romanov G.V. Asfal'tenovye nanoagregaty: struktura, fazovye prevrashcheniia, vliianie na svoistva neftianykh sistem [Asphaltene nanoaggregates: structure, phase transformations, influence on the properties of oil systems]. Uspekhi khimii, 2011, vol.80, no.10, pp.1034-1050. DOI: 10.1070/RC2011v080n10ABEH004174

2. Glushchenko V.N., Silin M.A., Gerin Iu.G. Neftepromyslovaia khimiia. Vol.V. Preduprezhdenie i ustranenie asfal'tenosmoloparafinovykh otlozhenii [Oilfield chemistry. Vol.V. Prevention and removal of asphaltene-osmoloparaffin deposits]. Moscow, Interkontakt Nauka, 2009, 475 p.

3. Klassen V.I. Omagnichivanie vodnykh sistem [Magnetization of water systems]. Moscow, Khimiia, $1978,180 \mathrm{p}$.

4. Loskutova Iu.V., Iudina N.V. Vliianie magnitnogo polia na strukturno-reologicheskie svoistva nefti [The influence of magnetic field on structural-rheological properties of oil]. Izvestiia Tomskogo politekhnicheskogo universiteta, 2006, vol. 309, no.4, pp.104-109.

5. Pivovarova N.A. Intensifikatsiia protsessov pererabotki uglevodorodnogo syr'ia vozdeistviem postoiannogo magnitnogo polia [Intensification of hydrocarbon processing by influence of a constant magnetic field]. Abstract of Doctor's degree dissertation. Moscow, 2005, 50 p.

6. Kolesnikova E.D. Vozdeistvie slabykh magnitnykh polei na protsessy kristallizatsii i plavleniia lineinykh polimerov [Influence of weak magnetic fields on crystallization and melting of linear polymers]. Abstract of $\mathrm{Ph}$. D. thesis. Voronezh, 2007, 23 p.

7. Kamalova N.S. Vliianie slabykh impul'snykh magnitnykh polei na mekhanicheskie i adsorbtsionnye svoistva modifitsirovannoi drevesiny [Influence of weak pulsed magnetic fields on the mechanical and adsorption properties of modified wood]. Abstract of Ph. D. thesis. Voronezh, 2008, 22 p.

8. Kal'chenko S.V. Vozdeistvie ul'trazvuka i impul'snogo magnitnogo polia na vysokomolekuliarnyi biokompozit [The effect of ultrasound and pulsed magnetic field on a high molecular biocomposite]. Abstract of $\mathrm{Ph}$. D. thesis. Voronezh, 2011, 18 p.

9. Spiridonov R.V., Demakhin S.A., Kivokurtsev A.Iu. Magnitnaia obrabotka zhidkostei $\mathrm{V}$ neftedobyche [Magnetic treatment of liquids in oil production]. Saratov, Kolledzh, 2003,136 p.

10. Iniushin N.N., Ishemguzhin E.I., Kashtanova L.E., Laptev A.B. et al. Apparaty dlia magnitnoi obrabotki zhidkostei [Apparatus for magnetic treatment of liquids]. Ufa, Reaktiv, 2000,147 p.

11. Shammazov A.M., Khaidarov F.R., Shaidakov V.V. Fiziko-khimicheskoe vozdeistvie na perekachivaemye zhidkosti [Physical and chemical effects on pumped liquids]. Ufa, 2003, 232 p.

12. Laptev A.B. Metody i agregaty dlia magnitogidrodinamicheskoi obrabotki vodoneftianykh sred [Methods and aggregates for magnetic hydrodynamic 
processing of water-oil matter]. Abstract of Doctor's degree dissertation. Ufa, 2007, 48 p.

13. Oborudovanie dozirovaniia reagentov, ustanovki magnitnoi obrabotki i pr. Inkom-neft' [Reagent dosing equipment, magnetic treatment plants etc. Inkomp-oil], available at: http://incomp.nt-rt.ru (accessed: 07 June 2016).

14. Borsutskii Z.R., Zlobin A.A., Semenov V.V., Tul'bovich B.I. Ustroistvo dlia magnitnoi obrabotki zhidkosti [Device for magnetic treatment of liquid]. Patent no. $2085507 \mathrm{kl}$. C02F1/48, 1997.

15. Borsutskii Z.R., Zlobin A.A Ustroistvo dlia magnitnoi obrabotki zhidkosti [Device for magnetic treatment of liquid]. Patent 2127708 Rossiiskaia Federatsiia kl. C02F1/48, 1999.

16. Zlobin A.A., Iushkov I.R. Analiz raboty magnitnykh aktivatorov dlia zashchity ot parafinootlozhenii [Analysis of the work of magnetic activators for the protection from the paraffin depositions]. Neftianoe khoziaistvo, 2011, no.10, pp.35-37.

17. Postnikov V.V. Fazovye i strukturnye prevrashcheniia $\mathrm{v}$ diamagnitnykh materialakh posle vozdeistviia slabykh magnitnykh polei [Phase and structural transformations in diamagnetic materials after the influence of weak magnetic fields]. Abstract of Doctor's degree dissertation. Voronezh, 2004, $45 \mathrm{p}$.

18. Morgunov R.B., Buchachenko A.L. Magnitoplastichnost' i magnitnaia pamiat' $\mathrm{V}$ diamagnitnykh tverdykh telakh [Magnetoplasticity and magnetic memory in diamagnetic solids]. Zhurnal eksperimental'noi $i$ teoreticheskoi fiziki, 2009, vol.136 iss.3(9), pp.505-515.
19. Zel'dovich Ia.B., Buchachenko A.L., Frankevich E.L. Magnitno-spinovye effekty $\mathrm{v}$ khimii i molekuliarnoi fizike [Magnetic spin effects in chemistry and molecular physics]. Uspekhi fizicheskikh nauk, 1988, vol.155, no.1, pp.3-45. DOI: 10.3367/UFNr.0155.198805a.0003

20. Buchachenko A.L., Sagdeev R.Z., Salikhov K.M. Magnitnye i spinovye effekty $\mathrm{v}$ khimicheskikh reaktsiiakh [Magnetic and spin effects in chemical reactions]. Novosibirsk, Nauka, 1978, 296 p.

21. Siuniaev Z.I., Siuniaev R.Z., Safieva R.Z. Neftianye dispersnye sistemy [Oil dispersed systems]. Moscow, Khimiia, 1990, 224 p.

22. Zlobin A.A. Experimental research of nanoparticle aggregation and self-assembly in oil dispersed systems. Bulletin of Perm National Research Polytechnic University. Geology. Oil \& Gas Engineering \& Mining, 2015, no.15, pp.57-72. DOI: 10.15593/2224-9923/2015.15.7

23. Zlobin A.A. Teoriia i praktika primeneniia iadernogo magnitnogo rezonansa $\mathrm{v}$ fizike neftianogo plasta [Theory and practice of application of nuclear magnetic resonance in the physics of the oil reservoir]. Perm': Izdatel'stvo PM, 2015, $271 \mathrm{p}$.

24. Unger F.G., Andreeva L.N. Fundamental'nye aspekty khimii nefti. Priroda smol i asfal'tenov [Fundamental aspects of petroleum chemistry. Nature of resins and asphaltenes]. Novosibirsk, Nauka, 1995, 192 p.

25. Rogachev M.K., Strizhenev K.V. Bor'ba s oslozhneniiami pri dobyche nefti [Overcoming the challenges while oil production]. Moscow, Nedra-Biznestsentr, 2006, 295 p.

26. Rozantsev E.G., Sholle V.D. Organicheskaia khimiia svobodnykh radikalov [Organic Chemistry of Free Radicals]. Moscow, Khimiia, 1979, 344 p.

\section{Библиографический список}

1. Ганеева Ю.М., Юсупова Т.Н., Романов Г.В. Асфальтеновые наноагрегаты: структура, фазовые превращения, влияние на свойства нефтяных систем // Успехи химии. - 2011. - Т. 80, № 10. - С. 1034-1050. DOI: 10.1070/RC2011v080n10ABEH004174

2. Глущенко В.Н., Силин М.А., Герин Ю.Г. Нефтепромысловая химия. Т. V. Предупреждение и устранение асфальтеносмолопарафиновых отложений. - M.: Интерконтакт Наука, 2009. - 475 с.

3. Классен В.И. Омагничивание водных систем. М.: Химия, 1978. - 180 с.

4. Лоскутова Ю.В., Юдина Н.В. Влияние магнитного поля на структурно-реологические свойства нефти // Известия Томского политехнического университета. - 2006. - Т. 309, № 4. - С. 104-109.

5. Пивоварова Н.А. Интенсификация процессов переработки углеводородного сырья воздействием постоянного магнитного поля: автореф. дис. ... д-ра техн. наук. - М., 2005. - 50 c.

6. Колесникова Е.Д. Воздействие слабых магнитных полей на процессы кристаллизации и плавления линейных полимеров: автореф. дис. ... канд. физ.-мат. наук. - Воронеж, 2007. - 23 с.

7. Камалова Н.С. Влияние слабых импульсных магнитных полей на механические и адсорбционные свойства модифицированной древесины: автореф. дис. ... канд. физ.-мат. наук. - Воронеж, 2008. - 22 с.

8. Кальченко С.В. Воздействие ультразвука и импульсного магнитного поля на высокомолекулярный биокомпозит: автореф. дис. ... д-ра физ.мат. наук. - Воронеж, 2011. - 18 с.

9. Спиридонов Р.В., Демахин С.А., Кивокурцев А.Ю. Магнитная обработка жидкостей в нефтедобыче. Саратов: Колледж, 2003. - 136 с.

10. Аппараты для магнитной обработки жидкостей / Н.Н. Инюшин, Е.И. Ишемгужин, Л.Е. Каштанова, А.Б. Лаптев [и др.]. - Уфа: Реактив, 2000. - 147 с.

11. Шаммазов А.М., Хайдаров Ф.Р., Шайдаков В.В. Физико-химическое воздействие на перекачиваемые жидкости. - Уфа, 2003. - 232 с.

12. Лаптев А.Б. Методы и агрегаты для магнитогидродинамической обработки водонефтяных 
сред: автореф. дис. ... д-ра техн. наук. - Уфа, 2007. $-48 \mathrm{c}$.

13. Оборудование дозирования реагентов, установки магнитной обработки и пр. Инкомп-нефть [Электронный pecypc]. - URL: http://incomp.nt-rt.ru (дата обращения: 07.06.2016).

14. Устройство для магнитной обработки жидкости: пат. № 2085507 кл. С02F1/48 / Борсуцкий 3.Р., Злобин А.А., Семенов В.В., Тульбович Б.И.; заявл. 23.06.1995; опубл. 27.07.1997. - Бюл. № 21.

15. Устройство для магнитной обработки жидкости: пат. 2127708 Рос. Федерация кл. C02F1/48 / Борсуцкий 3.Р., Злобин А.А.; заявл. 13.11.1996; опубл. 20.03.1999. - Бюл. № 8.

16. Злобин А.А., Юшков И.Р. Анализ работы магнитных активаторов для защиты от парафиноотложений // Нефтяное хозяйство. - 2011. - № 10. C. $35-37$.

17. Постников В.В. Фазовые и структурные превращения в диамагнитных материалах после воздействия слабых магнитных полей: автореф. дис. ... канд. физ.-мат. наук. - Воронеж, 2004. - 45 с.

18. Моргунов Р.Б., Бучаченко А.Л. Магнитопластичность и магнитная память в диамагнитных твердых телах // Журнал экспериментальной и теоретической физики. $-2009 .-$ T. 136, вып. 3 (9). - С. 505-515.
19. Зельдович Я.Б., Бучаченко А.Л., Франкевич Е.Л. Магнитно-спиновые эффекты в химии и молекулярной физике // Успехи физических наук. - 1988. - Т. 155, № 1. - C. 3-45. DOI: 10.3367/UFNr.0155.198805a.0003

20. Бучаченко А.Л., Сагдеев Р.З., Салихов К.М. Магнитные и спиновые эффекты в химических реакциях. - Новосибирск: Наука, 1978. - 296 с.

21. Сюняев 3.И., Сюняев Р.3., Сафиева Р.3. Нефтяные дисперсные системы. - М.: Химия, 1990. $224 \mathrm{c}$.

22. Злобин А.А. Экспериментальные исследования процессов агрегации и самосборки наночастиц в нефтяных дисперсных системах // Вестник Пермского национального исследовательского политехнического университета. Геология. Нефтегазовое и горное дело. - 2015. - № 15. C. 57-72. DOI: $10.15593 / 2224-9923 / 2015.15 .7$

23. Злобин А.А. Теория и практика применения ядерного магнитного резонанса в физике нефтяного пласта. - Пермь: Издательство ПМ, 2015. - 271 с.

24. Унгер Ф.Г., Андреева Л.Н. Фундаментальные аспекты химии нефти. Природа смол и асфальтенов. Новосибирск: Наука, 1995. - 192 с.

25. Рогачев М.К., Стрижнев К.В. Борьба с осложнениями при добыче нефти. - М.: НедраБизнесцентр, 2006. - 295 с.

26. Розанцев Э.Г., Шолле В.Д. Органическая химия свободных радикалов. - М.: Химия, 1979. - 344 с.

Please cite this article in English as:

Zlobin A.A. Study of mechanism of oil magnetic activation in order to protect production wells from wax deposition. Bulletin of PNRPU. Geology. Oil \& Gas Engineering \& Mining, 2017, vol.16, no.1, pp.49-63. DOI: 10.15593/2224-9923/2017.1.6

Просьба ссылаться на эту статью в русскоязычных источниках следующим образом:

Злобин А.А. Изучение механизма магнитной активации нефти для защиты добывающих скважин от асфальтеносмолопарафиновых отложений // Вестник Пермского национального исследовательского политехнического университета. Геология. Нефтегазовое и горное дело. - 2017. - Т.16, №1. - C.49-63. DOI: 10.15593/2224-9923/2017.1.6 